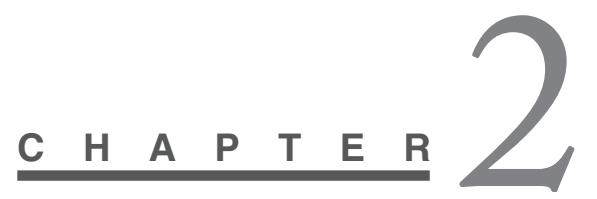

\title{
Singapore between Cosmopolis and Nation
}

\author{
Anthony Reid
}

Singapore is often seen from a postcolonial perspective as one of the anomalies left behind by the British empire; a port-city trying to become a state. This paper takes an opposite perspective, grounded in the long history of "central Southeast Asia", the corridor between Bangkok and Jakarta. The Peninsula, and the hinterland of the two vital Straits of Melaka and Sunda, has for millennia been a place of exchanges, transshipments and portages. It is an area "made for merchandise", with poor agricultural soils but many strategic locations for the necessary points of exchange between the Indian Ocean and the South China Sea.

The mixed population of Chinese, Indians, Southeast Asians and Europeans in such cosmopolitan entrepôts was not an accident of colonial displacement, but a necessity for the regional role in world trade. Seen from this perspective, the anomaly may be the 20th century, with its attempt to impose an alien concept of nation on the cosmopoleis which had taken root there. The 21st century may well see a reversal of this pressure, and a return to the region's natural need for cosmopolis. 


\section{Definitions}

In using the term "cosmopolis", I am indebted not so much to the cosmopolitan-heartlander dichotomy of Singapore discourse, but to Immanuel Kant and his newly fashionable Towards Perpetual Peace (1795), where cosmopolis is used to denote a world system where differences between communities are accommodated in a kind of federal structure. ${ }^{1}$ My agenda is more modest than Kant's universal one, and my use of the term is restricted to an urban context. I use it to describe a form of city-state relatively well-developed in Central Southeast Asia (as in some other global crossroads), where a necessarily plural community is governed through leaders themselves cosmopolitan in culture and able to mediate between groups. I will however endorse one finding of Kant, that while religion and language separate nations, "the spirit of commerce unites them", so that the task of cosmopolis is to mediate these two contrary impulses.

As a kind of antithesis of cosmopolis, we place the familiar modern idea of nation, as a community imagined as having important elements of cultural homogeneity, the location of which coincides, or should coincide, with the territorial borders of a nation-state and the authority of a single government. Putting aside for the moment a few antecedents of the national idea which may have made a marginal earlier impact in some quarters of Southeast Asia, I will argue that this was a concept imposed by Europeans, and that it remained alien to the region until the 20th century's remarkable love affair with nationalism. One of the features of 20th-century nationalism was to try to impose the nation backwards onto a cosmopolitan past, claiming the "Empayer" of Melaka, Brunei or Majapahit as the antecedent of modern nation-states. In this construct, cosmopolis is embarrassing, and where it cannot be avoided, has to be put down to aberrant colonial schemes to divide and rule. I want to proceed in the opposite direction, tracing the cosmopolitanism of quite ancient times forward to the point where it is overtaken by nation in the 20th century, and to see whether this makes a difference to how we imagine the future.

The third element of my title, "Central Southeast Asia", is the Bangkok-Jakarta central axis of Southeast Asia. It is formed by the world's longest peninsula, nearly blocking the shipping route between East Asia and the rest of Eurasia and Africa, the two Straits through which it obliges that shipping to pass, and the adjacent littoral. It is thus a natural place of entrepôts and meeting places, set moreover in a climatic zone relatively unfriendly to intensive agriculture. The high year-round 
rainfall, thick vegetation and mediocre soils made this in the longue durée a region very difficult to develop for rice agriculture, so that hunter-gatherer populations, as well as tigers and elephants, dominated the hinterlands. The entrepôts which developed at strategic locations in this zone took for granted that they would import most of their food staples by sea. Only in the 19th and 20th centuries were the malarial lowlands of this region harnessed on any significant scale for permanent agriculture. I have called it elsewhere the historically "empty centre" of Southeast Asia, or the "low centre" of my saucer model of Southeast Asian identity. ${ }^{2}$ Although Central Southeast Asia developed significant centres of wet-rice agriculture in the 20th century, it remains today what it has been throughout recorded history, one of the most urban-dominated zones of the world.

The first major population concentrations to arise in this zone must have been watering points for vessels, and harbours where cargoes were discharged from vessels and transferred to portages across the rivers and passes of the peninsula. Paul Wheatley called the whole long period between about 550 and $1400 \mathrm{CE}$ "the Isthmian Age", because of the importance of little port-states at both ends of the portages across the peninsula. ${ }^{3}$ At times when piracy was under control and the sea route of the Straits was viable, entrepôts were still essential for vessels waiting for a change of monsoon to take them safely home on a following wind. It was therefore essential to the viability of such entrepôts to be hospitable both to traders coming across the Indian Ocean from India and the Middle East, and to those coming across the South China Sea. A third strand, usually also present, were traders bringing the spices and forest products of the Indonesian Archipelago to this central zone in exchange for textiles and other manufactures from China and India.

Cosmopolis was therefore built into the nature of the successful entrepôt in this zone; but security was not. The problem for cosmopolis in this part of the world was to find a form of government that would protect commercial communities rather than preying upon them. Where it happened, the formula had almost nothing to do with nation, but much with the supernatural charisma of kingship. Since monarchs were themselves one of the greatest dangers to the accumulation of wealth, some of the most successful comopoleis, Banten and Patani in the early 17 th century or Aceh in the late 17th, chose a female ruler or a minor as a means to combine royal charisma with the effectively oligarchic power of the leaders of commercial communities. ${ }^{4}$ 


\section{Precolonial Cosmopoleis}

Chinese and Arab sources since the sixth century have reported numerous collecting and trade centres with puzzling names within this zone, of which the most important was that known to the sources as San Fo Chih, Sribuza or Srivijaya. They make clear that it was a crossroads, "an important thoroughfare on the sea-routes of the foreigners on their way to and from [China]", as Chou Ch'u-fei reported it. ${ }^{5}$ The earliest inscriptions in the Malay language are here, and they are in the form of curses, threatening horrible things if the diverse groups who took the oath at the stone failed in their duty of loyalty. It was, in other words, a very plural polity, held together by largely magical means.

Although Srivijaya has surprisingly little to say for itself, the way it is remembered in the Malay texts is interesting. The Hikayat Hang Tuah records a longstanding concept of Malay sovereignty, that a charismatic ruler attracts a diverse trade and population.

It became known among all nations that Bukit Seguntang had a king ... whose demeanour was exceedingly kind and courteous, and who cared for all foreign traders and scholars. After this was heard in all countries, people from here and there came to Bukit Seguntang; from the sea and from the land they came to approach this king. ${ }^{6}$

The surest historical evidence for the diversity of foreigners who spent time in Srivijaya, however, was the description of the city by the seventhcentury Chinese monk, I Qing. He insisted that there were more than a thousand Buddhist priests in its monasteries, and advised pilgrims from China to spend time there to master Sanskrit and Pali before travelling on to the holy places of India. Where there were Indian and Chinese monks maintaining these language abilities, there must have been Indian and Chinese commercial communities maintaining the monks. Chinese trading communities are also likely to have helped manage the tributary trade between Srivijaya and Tang China, so important for the commerce of the whole region. One of the heirs of Srivijaya was 14th-century Temasek, of which Wang Dayuan reported that "the men and women dwell together with Chinese people" - which suggests there was not yet a developed cosmopolis with separate ethnic quarters, but rather a mixing tending towards hybridity. ${ }^{7}$

The evidence of the Nakhon Si Thammarat chronicle, one of the oldest Peninsula literary productions, is intriguing as to the very plural origins of what eventually became Thai Buddhist and Malay Muslim polities on the 
Peninsula. The origins of the Peninsula dynasties are there traced to a moment of Chinese interaction with the salt-exporting centre of Phetburi in the Gulf of Siam at a time evidently pre-dating the rise of Ayutthaya - perhaps equating to the 13th century. The ruler of Phetburi, himself possibly a Khmer with origins in Angkor, provides sandalwood to a visiting Chinese ship, and is rewarded by the Chinese emperor with his daughter (or granddaughter) by a Champa princess, Candradevi. She is sent to Phetburi with 19 ships and 7,400 servants and concubines to serve the king of Phetburi. He then sends out his sons and retainers, some endowed with Chinese consorts and Khèk (likely to be Austronesian, or possibly Khmer) auxiliaries, to found other polities including the predecessor of Nakhon. The principal son, ancestor-figure of the Nakhon line, in turn sends out Khèk in boats to become rajas of the Khèk principalities further south, including areas we now know as Trang, Songkhla, Patani, Kedah and Pahang. ${ }^{8}$ This type of source has been recently used by Chris Baker to rewrite the origins of the Thai kingdom as an ethnically diverse trading emporium rather than the successor of Sukhothai as in the national canon. ${ }^{9}$

What we know of Peninsula ports like Mergui, Tenasserim, Phukhet, Penang, Kedah and Melaka on the west coast, and Nakhon Sithammarat, Songkhla and Patani on the east coast, in the 15th to 18th centuries shows essentially mixed trading populations. Indian traders of various sorts tended to dominate the commerce of the west coast cities, and Chinese those of the east coast, but ethnic categories were in constant flux as male longdistance traders married or cohabited with female Southeast Asians who did the local marketing. Their children formed new commercial diasporas in the region, often referred to as Malay if Muslim, and Chinese if not.

The sources are the most helpful for pre-1511 Melaka. We know that a hybridised Malay-speaking Muslim elite ruled over an intensely cosmopolitan entrepôt by developing a ritualised charismatic monarchy, and by putting the highest possible priority on succeeding Srivijaya as the privileged tributary gateway from Central Southeast Asia to the China market. Melaka's most successful ruler, Sultan Mansur (r.1459-1477), was saluted as a cosmopolitan king in 1472 by the King of Ryukyu: "your virtues are known to neighbouring countries, and you put yourself in the place of others and make no distinctions among various peoples, loving others as you do yourself and treating people equally". ${ }^{10}$ Tomé Pires reported that 84 distinct languages were spoken by the people of prePortuguese Melaka. ${ }^{11}$ The most important commercial communities, each settling in their own districts with wealthy bilingual headmen over them, 
were Gujaratis $(1,000)$, other North Indians, Arabs and Persians $(3,000)$, South Indians (unspecified, but more numerous than the former); Javanese (10,000 settled in Upeh), Mons from Pegu, Luzons from Manila and Brunei, Ryukyuans, Chinese and various peoples from the Archipelago. ${ }^{12}$

The Thai-ruled trading cities in the northern half of the peninsula were also known for their intense variety of trading groups. When we have fuller descriptions of Ayutthaya in the 17th century, one claimed that "almost half of the kingdom is populated by Peguans, taken in war; ... there are also many Lao". The royal guard was Chinese and Muslim; and the standing army composed in equal measure of Thai, Mon, Khmer and Lao. ${ }^{13}$ Another French source emphasised how the freedom of its commerce attracted to Ayutthaya:

a great multitude of strangers of different nations, who settled there with the liberty of living according to their own customs, and of publicly exercising their several ways of worship. Every nation possesses its own quarter... Moreover every nation chooses its chief. ${ }^{14}$

The best early modern Southeast Asian defence of pluralism was perhaps that of the Thai King Narai (r.1657-1688), declining a request from King Louis XIV of France that he become a Catholic Christian. He expressed surprise that King Louis should expect everybody to have the same faith and rituals, whereas God himself seemed to rejoice in the great diversity of his human creation. "Ought not one to think that the true God takes as great pleasure to be honoured by different worships and ceremonies, as [he does] to be glorified by a prodigious number of creatures." ${ }^{15}$

Ayutthaya's successor, Bangkok, continued this pattern in the early 19th century. Though estimates of the flourishing cosmopolis' ethnic populations vary, most agreed that Thais were a small minority in a rich tapestry of Chinese (the largest category), Mons, Thais or Siamese, Lao, Vietnamese, Malays, and so forth. ${ }^{16}$

Further south in the Peninsula, the diversity was equally marked. Malay was the lingua franca in most ports, and hence, place names were expressed to foreigners in their Malay variants - Ligor, Singora, Ujung Salang or Junk Ceylon; not Nakhon, Songkhla and Phuket. The ruling family appears to have been basically Thai in Nakhon and Malay in Patani, but the elite was certainly bilingual, and there were any number of Chinese and Indian high officials at both places.

At the time of van Warwyck's visit to Patani in 1602, the most important figure in commercial and military affairs was said to be the Datu 
Seri Nara, a peranakan Chinese, or in the Dutchman's terms, "a Malay of Chinese origin", converted to Islam. ${ }^{17}$ Observers in the 17 th century noted that the Chinese trade was the life-blood of the city, ever since 2,000 Cantonese "pirates" (according to Ming annals) made it their base in the 1560s. ${ }^{18}$ Patani was then the kind of base for the Chinese Southeast Asian trade that Bangkok, Batavia and Singapore later became, with their ships sailing throughout the Archipelago as far as Makasar, and to Ayutthaya and Hoi An (Cochin-China). When Olivier van Noort discovered Chinese traders in Brunei in 1601, he found they were a community that had fled or been banished from China, and presented themselves as still very Chinese even under their own Patani king, with "the same laws as exist in China". ${ }^{19}$ But Patani traders in eastern Indonesia a generation later were classified as a kind of Malay, and it seems safe to assume that a considerable number of them did assimilate to the mobile Malayo-Muslim commercial elite which featured in all the ports eastward of Sumatra in the 17th and 18th centuries.

Cosmopolis, in other words, was built into the very fabric of the Peninsula's character, to an extent hard to match by any other area of comparable size on our planet, before the European impact.

\section{European Concepts of "Nation"}

The much-debated concept of "nation" had a long history in Europe going back to the Middle Ages, though it became politically central for certain early "nation-states" in the 16th century. ${ }^{20}$ Portugal was one of these, and the Netherlands took the concept of nation-state to unprecedented successes in the 17th century. If we exclude the eccentric imperial project of the early Ming emperors and their Zheng He fleets, it was the quarrelling Europeans who brought to the Indian Ocean for the first time the idea of using military force to support the commercial aims of one "nation" against its perceived competitors. Especially when projected into foreign, Asian waters, this programme rested on new concepts of loyalty based on race, religion, and language.

The Portuguese and Spanish set out on their voyages of discovery at almost the identical moment, in 1492, when they took the major step towards the nationalist project of realising homogeneity within their borders, by expelling their Jews and Muslims. To Southeast Asia, the Portuguese introduced a spirit that is often described as crusading, but it is closer to the mark to say they projected overseas the religiously-coloured 
early nationalism of a small and compact people. Their visceral enemies were first the "Moors" whom they had fought down the Iberian Peninsula, but secondly the Protestant Dutch, who replaced the Muslims as enemy number one in Asia, and thirdly the Castilians with whom they bitterly contested exclusive rights in Asia.

Tomé Pires may have been the first to write the word "nation" in a Southeast Asian context when explaining why the classic cosmopolis of Melaka, ready as always to use Gujarati and other merchants to defend it, as well as the orang laut sea people, had fallen before a handful of passionately nationalist Portuguese.

The people did not back the king of Melaka, because in trading lands, where the people are of different nations (nacôes), these cannot love their king as do natives (naturall) without admixture of other nations. This is generally the case, and therefore the king was disliked, though his mandarins fought. ${ }^{21}$

The ruling elite of Melaka would have had difficulty understanding this point, completely alien to the explanatory frame adopted by the Melaka chronicle, which was largely written to explain the fall of the great city. It weaves a moral tale about cosmic retaliation for a breaking of the contract between Ruler and the ruled.22 Every Southeast Asian monarch had relied upon professional forces culturally different from himself, who could be relatively well trusted to be dependent on the king. Assorted Muslim and later Portuguese professional gunners served the mainland Buddhist states. In Melaka, even the exemplary "Malay" warrior Hang Tuah is quoted in chronicles as admitting to being "Hybridised Malay [Melayu kacukan], mixed up with Majapahit Javanese". ${ }^{23}$

Their early nationalism helped the Portuguese to win some battles, but it largely killed the golden goose of cosmopolis, which the Portuguese essentially sacrificed to their initial sense of nation as necessarily excluding Muslims. Titling himself "Lord of the conquest, navigation and commerce of Ethiopia, India, Arabia and Persia", King Manoel was too much prisoner of the national idea to allow his servants to play the necessary neutral role in the would-be Portuguese entrepôts. On the key sectors of trade where it had influence, the Portuguese crown sought to monopolise trade in the hands of either the crown itself (increasingly unable to cope with the demands) or merchants licensed by the crown. Only in Macao and Nagasaki, where the Portuguese were too weak to apply their dangerous ideas of nation, could they make substantial profits by operating within a kind of cosmopolis. 


\section{European Nation Ruling Asian Cosmopolis}

Of course, not all the cosmopolis was on the Asian side, or nation on the European. Firstly, the Portuguese onslaught onto Muslim shipping caused a reaction, whereby the expelled or injured Muslim merchants rallied behind rulers, particularly Aceh, willing and able to stand up to the Portuguese. We could identify a national response in Aceh, which in turn damaged its cosmopolis by excluding the Portuguese in the 16th century, and even the Chinese (on Islamic grounds) for some of the 17th. The 17th-century law against Thai women marrying foreigners is another such contradiction of the long-term tolerance which appears to mark Thai management of foreign traders. ${ }^{24}$

The Europeans for their part learnt quickly of the enormous advantages of cosmopolis, and built their own versions, albeit with a touch of nation in the way they ruled. The Portuguese were less successful than their successors largely because they made all the mistakes from which the Spanish, Dutch and English learnt.

The Spanish learnt something from Portuguese mistakes, but basically they were extraordinarily lucky. Though dreaming of spices and souls, Legazpi's conquistadors arrived in the Philippines just as China for the first time licensed its shippers to trade to the south legally, in 1567. Since their anti-Muslim bias did not get in the way of this arm of trade, the Spanish moved their headquarters in 1571 to the principal Chinese trading base at Manila, and took advantage of the boundless enthusiasm of Chinese traders for Mexican silver. Manila managed to become both the most important single Southeast Asian destination for Chinese traders until about 1640, and the most important for Japanese until about 1610 (when Hoi An took over), despite the paranoid outbreaks of Spanish nationalism that constantly threatened to kill this golden goose also. By 1603, there were about 20,000 Chinese residents in the city, largely self-governing, as well as 1,500 Japanese..$^{25}$

For our Central Southeast Asia story, however, the Spanish are important chiefly as a model for the Dutch in the 17th century, who more self-consciously learnt the lessons of how to build an Asian cosmopolis. The Dutch brought a more clearly established sense of nation, in which a republican ideal of the common participation of the property-holding elite was far more important than either religion or dynasty. The chief foes of their nationalism, however, were the Spanish and Portuguese, not the Muslim and Chinese traders they found in Asia. They managed, therefore, to be relatively clear-eyed about the commercial advantages of 
cosmopolis. Jan Pieterszoon Coen (1587-1629) was the most determined advocate of a permanent Dutch stronghold in Asia, emulating those of the Portuguese and Spanish, and he established it in 1619 by capturing Jakarta and renaming it Batavia. His goal was, as he explained to his Board of Directors,

to establish a place where so great a concourse of people would come to us, Chinese, Malay, Javanese, Klings and all other nations, to reside and trade in peace and freedom under Your Excellency's [VOC] jurisdiction, that soon a city would be peopled and the staple of the trade attracted, so that [Portuguese] Melaka would fall to nothing. ${ }^{26}$

These calculations were similar to those of Raffles two centuries later, when he argued that by attracting Asian traders through good conditions, Singapore would eclipse the Dutch settlements. But in his time, Coen was so far ahead of most English opinion that one nationalist English trader complained,

I cannot imagine what these Hollanders meane, to suffer these Maleysians, Chinesians and other Moores of these countries, and to assist them in theyr free trade through all the Indies, and forbidde it theyr own servants, countrymen and bretheren. ${ }^{27}$

In reality, Coen was heir to Dutch ideas about the nation, but fortunately for the persistence of Jakarta as Batavia, his scheme to develop a solid Dutch citizenry in Batavia to embody it was a failure. The Dutch-speaking European and Mestizo communities declined steadily in demographic significance as the city grew, from $29 \%$ of the population in 1632 to $23.5 \%$ in $1739 .{ }^{28}$

Within two years of its founding, there were 1,263 Chinese paying the city's poll tax, attracted or dragooned from Banten and other nearby sites, as well as from Chinese ships. They were engaged in service industries, construction, craft production and provisioning. Unlike Manila or Portuguese Melaka, Batavia did not particularly encourage Chinese or other Asians (unless they were Catholics and therefore potential enemies), to adopt the Calvinist faith of its rulers. The developed Dutch sense of an ethnically and culturally homogeneous nation here worked in favour of cosmopolis, by setting limits to the local hybridity tolerated in the Dutch community, and thereby necessitating a plural city.

During Batavia's commercial apogee between 1680 and 1730, it was probably the most important international entrepôt in Asia, and had an extremely diverse population. Of the 71,600 counted both inside and outside the walls in 1699, for example, $4.8 \%$ were European and Eurasian Christians: 11\% Asian Christians of very diverse ethnic backgrounds 
(Mardijkers); 16.2\% Chinese; 1.8\% Indians, chiefly Muslim, 3.5\% Malays; $31.6 \%$ assorted other Indonesians (Javanese and Balinese beginning to predominate); and 36\% slaves of chiefly east Indonesian background. ${ }^{29}$ Each of these categories was enormously varied internally, but the diasporic tendency to ally and identify with larger groups, especially where these had official status, was also in play here.

The two most economically important Asian categories for the trade of the city, Chinese and Malays (an essentially diasporic trading community having little in common with 20th-century understandings of the term), each had their own captains and administrative autonomy. From the outset, a prominent Chinese trader, So Bingkong, was appointed Captain of the Batavia Chinese, and his authority was reinforced with the right to certain monopoly revenues, in what became an entrenched pattern of Sino-Dutch economic partnership. Indian Muslims acquired their officer only in the 18 th century.

\section{British Rule and Southeast Asian Cosmopolis}

By the 19th century, Britain was certainly a nation-state, and the British imposed many of the fundamental monopolies of the nation-state in Asia. One of the first steps had to be clear boundaries within which British sovereignty was absolute and British laws, currency and institutions prevailed. The 19th century was unprecedented in the way the map of southern Asia (China-Korea-Vietnam had got there first) was painted in different colours, with lines demarcating one sovereignty from another. Burney, for example, pointed out to the Chancellor [Kalahom] of Siam:

the advantage of having regular boundaries established as soon as possible between the Siamese dominions and our conquests on the coasts of Tenasseri ... I added that the English earnestly desire to live in the vicinity of the Siamese as good friends and neighbours, and not in the same unsettled and unsocial terms as the Burmese had done; that for this reason we are anxious to have the boundary and rights of each party fixed, so as to prevent all chance of mistake or dispute between our subordinate officers. ${ }^{30}$

But being sated with nation in India and Burma, the British saw the merits of cosmopolis in Central Southeast Asia, and were very slow to encourage any imagining of nations there.

Francis Light, the pioneer of what became the British hegemony of the Peninsula, was appropriately fluent in both Thai and Malay, and had 
his principal base in Phuket before becoming the first British Resident of Penang in 1786. His infant settlement began with a diversity typical of the Peninsula. "Our inhabitants are composed of Chinese, Malays, Christians, Chulias, Siamese and Tannoes," he wrote a year after its foundation. ${ }^{31}$ In the 1820s, James Low explained the difficulties of administering justice in the settlement when the chief languages current were English, Hindustani, Tamil, Arabic, Telugu, Bengali, at least ten dialects of Chinese, Burmese, Mon, Siamese, Malay, Javanese, Buginese and Batak. ${ }^{32}$

The ports on the Peninsula side of the Malacca Straits became in the 19th and 20th centuries the archetype of cosmopolis, perhaps more resistant to the contrary needs of nation than any other corner of the globe. The British took cosmopolis to one of its highest levels by adding their own notion of a free port open to migration and trade to what they inherited - the indigenous notion of cosmopolis and Dutch legal arrangements within it. Penang and Singapore were open virtually to anyone, and attracted a diverse population. The proportion that could be considered "British" (though that category was not emphasised in censuses) never exceeded one per cent, though English and Malay became the linguae francae of an exceptionally mixed population.

No culture could be said to dominate Penang at that time, and the largest categories in the census of $1833-40 \%$ Malays; 22\% Chinese; $20 \%$ "Chulias" and 3\% "Bengalis" - were in practice much divided into different linguistic and cultural groups. Sumatrans, Burmese and Siamese were of similar demographic weight to the Europeans, while communities of Arabs (142 in 1833), Parsees or Zoroastrians (51) and Armenians (21) were very small and yet capable of sustaining their own social and religious institutions. ${ }^{33}$ The same was true of Singapore, though the proportions differed. Chinese were $41 \%$ (and predominately male), Malays 34\%, Tamils $9 \%$, "Bugis, Balinese, etc." (the only majority female category, thanks to the marriage market) $8 \%$, and North Indians 2.4\%, "native Christians" 1.4\%. ${ }^{34}$ Arab, Jewish, Armenian and German communities were smaller but economically and socially significant, with their own religious and social institutions (the German club was established before Germany was, in 1856). ${ }^{35}$ In the 20th century, Russian and Japanese communities became significant, and increasingly also a French-speaking one. Religious festivals, marriages, funerals, national days, and visiting troupes from external homelands were the occasions for each group to celebrate its culture and to put it on show for the cosmopolitan audience. 


\section{The 20th-Century Imposition of Nation on Cosmopolis}

"Central Southeast Asia", like the rest of the world, was carved into nationstates in the 20th century. Imperial nationalism required sharp boundaries and undisputed sovereignty within them; anti-imperial nationalism provided the missing ingredients of imagined communities — popular mobilisation and the aspiration for a uniform and universal education. The Dutch unified the archipelago with rather extreme forms of monopoly, mercantilism and protectionism at different times. In consequence, Batavia/Jakarta was in uninterrupted decline as cosmopolis, relative to other centres, from about 1760 until today. Having established the supremacy of the nation over the cosmopolis by the end of the 18 th century, there could be no logical way out except eventually to democratise that nation through some form of majority rule. Indonesia's transition to independence would have been on a more pluralist, federal basis without the revolution which followed the Japanese surrender, but it is difficult to imagine a decolonisation process that could have revived the once-great Batavia cosmopolis - particularly in competition with Singapore.

Siam began the transition to nation-state in the 1890 s as the selfstrengthening essential to holding off its aggressive imperial neighbours. The process of transition became more drastic with the 1932 revolution, and reached its most extreme under the Japanese-aligned nationalist government of Phibun Songkhram in 1938-1944. Nation was explicitly imposed on cosmopolis. A single Thai identity was defined, with prescribed patterns of (western) dress and behaviour, Chinese and Malay newspapers and schools were almost all closed, and the separate system of Islamic inheritance and marriage law was abolished in favour of a uniform Thai system. ${ }^{36}$

At the centre of "Central Southeast Asia", in British Malaya, cosmopolis was most strongly entrenched. Even the idea of a nation-state was barely established. The strongest nationalist movements prior to $1945 \mathrm{had}$ been in support of other identities - Chinese, Indian, and Indonesian. Even the Japanese rulers of the southern Peninsula in 1942-1945 used the nationalisms of China, India, Indonesia and Thailand to mobilise feelings against the Allies, not any local sense of nation. Not surprisingly, this was the last corner of colonial Asia to gain its independence, in 1957 (as Malaya) and 1963 (enlarged as Malaysia), after a lengthy communist insurgency and various unsuccessful schemes to create a single citizenship. 
Even the education system could not be effectively unified, as separate Chinese, Malay and English language schools continued to mould students towards different aspirations. The very concept of national culture had to be plural, representing a cosmopolitan mosaic of different traditions.

When the experiment to unite Malaya, Singapore, Sarawak and North Borneo failed in 1965, Singapore was split off from Malaysia to form its own state. Two very different visions of how to build a nation-state on such a cosmopolitan base had fatally collided. Each of the separated parts would proceed to attempt to realise its own vision in the ensuing decade, the Malaysian increasingly Malay-dominated, the Singaporean dominated by an English-educated meritocratic elite. As the Singapore Prime Minister later asked rhetorically, "How were we to create a nation out of a polyglot collection of migrants from China, India, Indonesia and several other parts of Asia?" 37

On hindsight, the 1960s can be seen as the peak of what James Scott called "high modernism", and its assumption that the task of the state was to create a relatively homogeneous nation. In both Singapore and Malaysia, cosmopolis continued, though assailed in Malaysia by escalating demands for Malay language and deference to Islam, and in Singapore by an ambitious programme of integrated housing and education. As increasingly global competition created an international context where the advantages of cosmopolis could not be ignored, it made a predictable comeback. Jean-Louis Margolin already drew attention recently to "the great return of immigration", and the process was further marked at the 2000 census. $^{38}$

The Singapore figures show the turnaround in the last decades of the nationalist century. Singapore's foreign-born population, one clear measure of the strength of cosmopolis in the mix, has usually been among the highest in the world, reflecting its status as cosmopolis par excellence. But this proportion showed a consistent decline throughout the 20th century, as migration from China, India and Indonesia largely ceased, domestic birth-rates soared, and the pressures of nation made themselves felt. The foreign-born proportions fell from a world-beating $72 \%$ in the 1921 census to $35 \%$ in that of 1957 and $21.8 \%$ in that of 1980 . Since then, however, it has risen to $24 \%$ in 1990 and $33.6 \%$ in 2000 , almost back to the level of $1957 . .^{39}$ Foreign contract workers, down to as low as 100,000 in the early 1980s, reached 530,000 in $1999 . .^{40}$ As the economy picked up, the total non-resident foreign population reached 875,000 at the end of 2006, representing a $10 \%$ increase on the previous year. ${ }^{41}$ 
By the end of the 20th century, the public rhetoric of nation appeared both less necessary in itself and less opposed to cosmopolis. Public leaders appealed to make Singapore "a cosmopolitan centre, able to attract, retain and absorb talent from all over the world", ${ }^{42}$ or "a global hub where people, ideas and capital come together". ${ }^{43}$ Prime Minister Lee Hsien Loong's 2006 National Day speech took this approach to new heights, making the need to attract large numbers of talented migrants its major theme. He seized the opportunity to lecture his audience that "each one of us, we have to welcome immigrants". ${ }^{44}$ And rather like the theme of this chapter, he appealed to the cosmopolitan immigrant past of Singapore to justify its cosmopolitan future.

Singapore offers something unique. We are an Asian society with an Asian heritage and culture and roots and yet we are an open and a cosmopolitan society. We use English as a common language, we keep our mother tongues and our cultures intact and alive and people from many cultures and backgrounds can come here, live here, be comfortable here and enjoy, integrate into our society. Become Singapore and yet retain what is unique about them and the links which they have back to their own cultures, their own homelands, their own sense of identity. And this is not just the three major races, Chinese or the Indians or the Malays but also many other smaller groups. In the earlier generations, we had Parsis, we had Jews from Iraq, we had Armenians, we had Arabs - little, little groups came to Singapore and made their home here and made their contribution here. Today, we get people from all over the world too. We have people from Turkey, there are Portuguese, somebody from Venezuela, somebody from Morocco, even a Korean or two, some Russians. And they add colour and diversity to this society. ${ }^{45}$

Interestingly Malaysia has witnessed the same turnaround after the 1980 census, though from a lower level of foreign-born population. Even though Malaysian public rhetoric is still about nation, and very little about cosmopolitanism, its foreign-born population rose from the 1980 nadir of $4.6 \%$ to $5.6 \%$ in 1990 , and $8 \%$ in 2000 .

The interplay between cosmopolis and nation will continue in the 21st century. The needs of nation for cultural coherence and political community will not disappear, though they may seem less urgent as nation-states and their members are knitted ever more intimately into supranational communities and economies. The birth rate of Singapore, like most of urban Asia, has been declining sharply, below replacement level throughout the 1990s. In addition, Singaporeans emigrate at the rate of about a thousand a year. Without immigration, therefore, the total population would be 
rapidly ageing and in overall decline by the 2020s. We can be sure that Singapore, as supreme example of the type of cosmopolis that has long flourished in one of the historically most open crossroads of the world, will be increasingly interesting to a globalised world in which none can afford to isolate themselves behind a wall of homogenised national culture. Having managed to resist the demands of nation better than most should prove an asset in the 21st century, as it was not always in the 20th.

\section{Notes}

1. D. Held, Democracy and the Global Order: From the Modern State to Cosmopolitan Governance (Palo Alto, California: Stanford University Press, 1995); Daniele Archibugi, "Demos and Cosmopolis", New Left Review 13 (January-February 2002), Joel S. Kahn, “Anthropology as Cosmopolitan Practice?”, Anthropological Theory 3, 4 (December 2003).

2. Anthony Reid, "A Saucer Model of Southeast Asian Identity", Southeast Asian Journal of Social Science 27, 1 (1999): 7-23.

3. Paul Wheatley, The Golden Khersonese (Kuala Lumpur: University of Malaya Press, 1961).

4. Anthony Reid, "Charismatic Queens of Southern Asia”, History Today 53, 6 (June 2003): 30-5.

5. Cited Wheatley, The Golden Khersonese, p. 63

6. Kassim Ahmad, ed., Hikayat Hang Tuah (Kuala Lumpur: Dewan Bahasa dan Pustaka, 1964), p. 6.

7. Wang Dayuan, as translated in W.W. Rockhill, "Notes on the Relations and Trade of China with the Eastern Archipelago and the Coast of the Indian Ocean during the Fourteenth Century", T'oung Pao 16 (1915): 131.

8. David Wyatt, The Crystal Sands: The Chronicles of Nagara Sri Dharrmaraja (Ithaca: Cornell University Southest Asia Program, 1975), pp. 102-10. One of the Khèk tributaries thus founded is intriguingly listed as Aceh. Wyatt (see 104n5) translates Khèk throughout this section as Malay which, though politically more correct, means imposing a modern ethnic term backwards to a pre-Muslim period when no such term was known. Khèk literally means guest or outsider, and has come in modern Thai to be used somewhat disparagingly for Malays, and darker people and Muslims more generally.

9. Chris Baker, “Ayutthaya Rising: From Land or Sea?”, JSEAS 34, 1 (2003): 41-62.

10. Atsushi Kobata and Mitsugu Matsuda, eds., Ryukyuan Relations with Korea and South Sea Countries: An Annotated Translation of Documents in the Rekidai Hoan (Kyoto: Kobata, 1969), p. 114. Melaka's replies (in Chinese) to these letters were full of conventional phrases such as "All within the bounds of the four seas are brothers", but acknowledge that "traveling merchants come swarming to us from afar"; ibid., pp. 113, 118. 
11. Armando Cortesão, trans., The Suma Oriental of Tomé Pires (London, Hakluyt Society, 1944), p. 269.

12. Ibid., pp. 254-5, 281-2.

13. L'Abbe de Choisy, Journal du Voyage de Siam Fait en 1685 E 1686 (Paris: Chez Sebastien Mabre-Cramoisy, 1687), p. 242.

14. Simon de La Loubère, The Kingdom of Siam (1693, reprinted Kuala Lumpur: Oxford University Press, 1969), pp. 10-1, 112.

15. Cited by Guy Tachard, A Relation of the Voyage to Siam, Performed by Six Jesuits (London 1688, reprinted Bangkok, 1981), pp. 223-4.

16. The various accounts of Bangkok's population in the early 19th century are conveniently surveyed in B.J. Terwiel, Through Travellers' Eyes: An Approach to Early Nineteenth Century Thai History (Bangkok: Duang Kamol, 1989), pp. 224-33.

17. Wijbrandt van Warwyck, 1604, in Begin ende Voortgangh van de Vereenighde Neerlandtsche Geoctroyeerde Oost-Indische Compagnie, ed. Isaac Commelin (Amsterdam 1646, reprinted Amsterdam, 1974), Vol. II, p. 43.

18. J. van Neck, 1604, in Begin ende Voortgang II, pp. 16-7. Anthony Reid, Southeast Asia in the Age of Commerce, 2 vols. (New Haven: Yale University Press, 1988-93), II, pp. 211-2

19. J.W. Ljzerman, ed., De Reis om de wereld van Olivier van Noort 1598-1601 (The Hague: Nijhoff for Linschoten-Vereniging, 1926), p. 124.

20. Len Scales and Oliver Zimmer, eds., Power and the Nation in European History (Cambridge University Press, 2005).

21. Suma Oriental of Tomé Pires, p. 279 (Portuguese text p. 504).

22. The accounts of the fall of Melaka are in the Shellabear version (perhaps 1536), Sejarah Melayu (The Malay Annals), ed. W.G. Shellabear (Singapura: Malaya Publishing House, 10th printing 1961), pp. 272-6; and the Raffles version (1612), Sejarah Melayu. The Malay Annals, new edition, comp., Cheah Boon Kheng (Kuala Lumpur: MBRAS, 1998), pp. 267-70.

23. Hikayat Hang Tuah, p. 175. See also Anthony Reid, "Understanding Melayu (Malay) as a source of Diverse Modern Identities", Journal of Southeast Asian Studies 32, 3 (October 2001): 295-313.

24. G. Smith, The Dutch East India Company in the Kingdom of Ayutthaya, 16041694 (PhD diss., Northern Illinois University, 1974), pp. 286-7.

25. H. de la Costa, The Jesuits in the Philippines, 1581-1768 (Cambridge, Harvard University Press, 1967), pp. 68, 205; Charles Boxer, The Christian Century in Japan, 1549-1650 (Berkeley: University of California Press, 1951), p. 302

26. Coen 10.10.1616, in Jan Pieterszoon Coen: bescheiden omtrent zijn bedrijf in Indie, ed. H.T. Colenbrander, 4 vols. (The Hague: Nijhoff, 1919-22), I, p. 215.

27. Peter Floris 1615, cited Leonard Blussé and Felipe Fernandez-Armesto, eds., Shifting Communities and Identity Formation in Early Modern Asia (Leiden: CNWS, 2003), p. 182. 
28. Remco Raben, Batavia and Colombo: The Ethnic and Spatial Order of Two Colonial Cities, 1600-1800 (PhD diss., Leiden University, 1996), pp. 85-93; J.L. Blussé van Oud-Alblas, Strange Company: Chinese Settlers, Mestizo Women and the Dutch in VOC Batavia (PhD diss., KITLV, Leiden University, 1986), p. 84.

29. Calculated from tables in Raben, "Batavia and Colombo", Appendix III.

30. Journal of Burney, 15 February 1826, The Burney Papers, 5 vols. (Bangkok, 1910-14; reprinted Gregg International, 1971), I, pp. 85-6.

31. Cited in K.G. Tregonning, The British in Malaya (Tucson: University of Arizona Press, 1965), p. 46. Tannoes suggests a refugee community from Tenasserim, a Peninsula port that had recently been conquered by Burma from Siam, though since they are later described as Muslim, it would have to represent a (predominately Indian) Muslim commercial element of the city.

32. James Low, The British Settlement of Penang (Singapore, 1826; reprinted Kuala Lumpur: Oxford University Press, 1972), pp. 291-2.

33. Calculated from figures in ibid., pp. 125-6 and T.J. Newbold, Political and Statistical Account of the British Settlements in the Straits of Malacca (1839; reprinted Kuala Lumpur: Oxford University Press, 1971), pp. 54-5.

34. Newbold, Political and Statistical, pp. 284-5.

35. Charles Burton Buckley, An Anecdotal History of Old Times in Singapore, 1819-1867 (1902; reprinted Kuala Lumpur: Oxford University Press, 1965), pp. 629-70.

36. G. William Skinner, Chinese Society in Thailand: An Analytical History (Ithaca: Cornell University Press, 1957), pp. 261-72; Thanet Aphornsuvan, Paper presented to Conference "Plural Peninsula", Walailak University, Nakhon Si Thammarat, 2004, pp. 44-5.

37. Lee Kuan Yew, The Singapore Story I (Singapore: Prentice Hall, 1998), p. 22.

38. Jean-Louis Margolin, "Singapour: Le Grand Retour de l'Immigration: Dynamiques Migratoires en Asie Orientale”, Revue Européenne des Migrations Internationales 16, 1 (2000): 207-20.

39. Saw Swee Hock, The Population of Singapore (Singapore: ISEAS, 1999), p. 33; Singapore Census 2000.

40. Ibid.

41. Straits Times, 10 March 2007, S2.

42. Lee Kuan Yew, 2000, cited Brenda Yeoh and Shirlena Huang, "Foreign Talent' in Our Midst: New Challenges to Sense of Community and Ethnic Relations in Singapore", in Beyond Rituals and Riots: Ethnic Pluralism and Social Cohesion in Singapore (Singapore: Eastern Universities Press for IPS, 2004), pp. 316-7.

43. Prime Minister Goh Chok Tong, Speech to Opening of Parliament, 1999, cited ibid.

44. Lee Hsien Loong National Day Speech, 20 August 2006, at <http:/www. gov.sg/NDR06Engspeechtranscript.pdf> [accessed 2007].

45. Ibid. 